ルムブレンデの使用が一般になされている，リスホルム ブレンデを使用する場合，その格子比によって使用可能 な電圧が異なり，最も散乱線除去能率のよい電圧を使用 すべきでむやみに電圧だけを高くして撮影しても撮影 の目的は達せられない.

胸部X線写真の撮影条件は，散乱線除去装置（除去方 法）の能率を考え，X線装置の容䑁の範囲内で，出来る だけ高い電圧で撮影するととが望ましい，ということを 提唱します。

\section{0）医用X線 TVについて}

\section{島津製作所 \\ 津田 元久}

1942年に W. E. Chamberlain がけい光板を使ったX 線透視像の画質が低いととをなげいて，電子技術を応用 した像輝度増強装置の出現を待望する論文を Radiology に発表している.

この論文に応じて，1948年にウエスティングハウス社 の J. W. Coltman がイメジアンプリファイアを発表し， 同時に R. J. Moonがフライングスポット方式のX線テ レビショョンを発表した，乙の雨者は当時学会でも非常に 注目されて，その優少が競われたあののようであるが結 局イメジアンプリファイアが生き残ったのであった。 と こで特笽ずべきとは, Coltman はイメジアンプリフ アイアにテレビション装置を組合わせれば将来X線テレ ビションが奉現するであううと予見していたととであ る.

1952年になるとR. H. Morgan らが，汀い光板，シ ュミットレンズ扔よびイメジオルシコンを使ったX線テ レビジョンを作っている．乙の形式は今日であマルコニ 社で作られているが一応実用にされた最初のX線テレビ ジョンといえよう．1950年代の後半になるとイメジアン プリファイアとテレビション装置を組み合わせた形式の X線テレビショョンが商品として出現するようになってき た。 今日X線テレビジョンといえば80〜90\%までがての 形式でありそこのうちであビシコンを使ったあのが多い，

X線テレビジョンとけい光板の Burger ファントム透 視像を比較すると，明らかにX線テレビジョンの方がま さっている．とのととは像の明るさがX線テレビション の方が大きいためであると説明されている，また，闭者 のあいだの雑音（量子雑音）の違いむ醐質化大きな差を 作る原因になって招り，けい光板透視の場合の雑音がX 線テレビショョンの場合よりはるかて大きく，乙れがけい 炎板透視像の識别度を低下させている。

像の鮮鋭度，コントラストを総合的化評洒する手段と
して最近はレスポンス関数が使用されるようになって来 た．乙の手法はX線テレビショョンにあ応用されている。

X線テレビショョンにはイメジアンプリファイアが不可 久であることはすでに述べたが，イメジンプリファイ アについての最近のトピックは可変視野イメジアンプリ ファイアの出現である。乙れは一本のイメシ管で大小 2 種類の視野がとれるものであり，小視野側の方が画質が すぐれており，レスポンス関数で比較をしてあ小視野の 方がよい．X線テレビショョンの場合は特に小視野の画質 がよくなるので有利であるが，イメジ管内での像の縮小 率が小さいので輝度か低く，ためにX線量率を増さなけ ればならないのが久点である。

X線テレビショョンは実用化されてからまだ10年程度で あるのにあかかわらず今日のような普及をみており，将 来どのように発表するか子予断を許さないが，イメジアン プリファイアと撮像管を一体として伝送效率の高いX線 テレビションができるようになるのではなかろうか.

\section{(シンポジゥム)}

\section{胃の検診を主体としたX X 線 TV の諸問題}

坐長高尾 義人

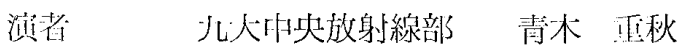
練早病院渡过行滩

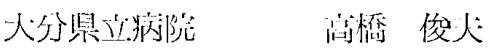

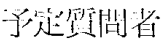

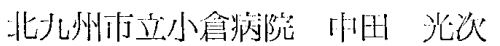
熊大归失放射線部阙田武雄

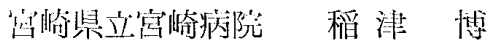
践児島県预防課有照 春夫

\section{胃の検診を主体とした X 線 TV の諸問題}

\section{大分県立病院}

高橋 俊夫

演題の件につき昨年に引続き本年むアンケート調查を 致しました。調查刘称 TV 112 台中 89 台即579\%の回答 を得ましたのでこれを基汇検討して見ますと昨年と本年 との間に著しい変化を示すととがわかりました，乙れは 約 1 力年間に於汀る進歩の傾向と見做すととが出来ると 思います，その主なむのを挙げて見ますと普及数では過 去 6 力年間に57台であったものが 112 台と11力月間に約 2 倍となって居ます。

型式别設耑数

$\begin{array}{ccc} & \text { リングスタンド型 } & \text { 起倒型 } \\ 1967-8 & 155_{i: \mathrm{i}}^{-i} & 32 i \uparrow \\ 1968-7 & 19 & 18\end{array}$
リモコン型
同不能型 